\title{
The Use of Core Warming as a Treatment for Coronavirus Disease 2019 (COVID-19): an Initial Mathematical Model
}

Marcela Mercado-Montoya1', Nathaniel Bonfanti², Emily Gundert², Anne Meredith Drewry³, Roger Bedimo ${ }^{4}$, Victor Kostov ${ }^{5}$, Konstantin Kostov6, Shailee Shah7, Erik Kulstad ${ }^{8}{ }^{*}$

\author{
ORCID IDS \\ Mercado-Montoya M (DD https:/orcid.org/0000-0002-1453-4690 \\ Bonfanti N (D) https://orcid.org/0000-0002-9564-9536 \\ Gundert E (D) https://orcid.org/0000-0001-5918-9088 \\ Drewry AM (D) https://orcid.org/0000-0001-6899-5196 \\ Bedimo R (D) https://orcid.org/0000-0001-9794-0389
}

\author{
Kostov $\vee$ (iD https://orcid.org/0000-0003-0150-8597 \\ Kostov K (D) https://orcid.org/0000-0003-3778-5051 \\ Shah S (D) https://orcid.org/0000-0002-1240-5414 \\ Kulstad E (D) https://orcid.org/0000-0002-9331-8266
}

\begin{abstract}
Introduction: Increasing data suggest that elevated body temperature may be helpful in resolving a variety of diseases, including sepsis, acute respiratory distress syndrome (ARDS), and viral illnesses such as SARS-CoV-2, which causes coronavirus disease 2019 (COVID-19). A mechanical provision of elevated temperature focused in a body region of high viral activity in patients undergoing mechanical ventilation may offer a therapeutic option that avoids arrhythmias seen with some pharmaceutical treatments. This study investigated the potential to actively provide core warming to the lungs of patients with a commercially available heat transfer device via mathematical modeling, and examined the influence of blood perfusion on temperature using this approach. Methods: Using the software Comsol Multiphysics, the authors modeled and simulated heat transfer in the body from an intraesophageal warming device, taking into account the airflow from patient ventilation. The simulation was focused on heat transfer and warming of the lungs and performed on a simplified geometry of an adult human body and airway from the pharynx to the lungs. Results: Simulations were run over a range of values for blood perfusion rate, since the heat capacity and density remain relatively constant. The highest temperature in this case is the device warming water temperature, and that heat diffuses by conduction to the nearby tissues, including the air flowing in the airways. At the range of blood perfusion investigated, maximum lung temperature ranged from 37.6 to $38.6^{\circ} \mathrm{C}$. Conclusions: The provision of core warming may offer an innovative approach to treating infectious diseases from viral illnesses such as COVID-19, while avoiding the arrhythmogenic complications of currently used pharmaceutical treatments.
\end{abstract}

KEYWORDS: COVID-19; Body temperature; Mathematical model

1.Universidad de Antioquia - Engineering Faculty - Bioengineering Department - Medellín, Colombia

2.UT Southwestern Medical Center - Departments of Emergency Medicine and Anesthesia/Critical Care - Dallas (TX), USA

3.Washington University - School of Medicine - Department of Anesthesiology - St. Louis (MO), USA

4.VA North Texas Health Care System - UT Southwestern Medical Center - Dallas (TX), USA

5.Walter Payton College Preparatory High School - Chicago (IL), USA

6.Life Science Angels - Chicago (IL), USA

7.Illinois Institute of Technology - Department of Bioengineering - Chicago (IL), USA

8.UT Southwestern Medical Center - Department of Emergency Medicine - Dallas (TX), USA

*Correspondence author: erik.kulstad@utsouthwestern.edu

Received: 04 May 2020 | Accepted: 27 May 2020 


\section{INTRODUCTION}

Traditionally, fever has been treated because its metabolic costs were felt to outweigh its potential physiologic benefit in an already stressed host ${ }^{1}$. However, increasing data suggest that fever may be a protective adaptive response that should be allowed to run its course under most circumstances ${ }^{2,3}$. The American College of Critical Care Medicine and the Infectious Diseases Society of America define fever as a body temperature of $38.3^{\circ} \mathrm{C}$ $\left(101^{\circ} \mathrm{F}\right)$ or higher ${ }^{4}$. Although one randomized controlled trial using physical cooling of mechanically ventilated patients with septic shock found a reduction in vasopressor dose and reduced early mortality when treating fever ${ }^{5}$, a growing number of studies have found either no clinically important benefit, or harms, in treating fever of infectious origin.

Studies have found that higher early fever is associated with a lower risk of death among patients with an ICU admission diagnosis of infection ${ }^{6,7}$ and that fever may enhance immune-cell function ${ }^{8,9}$, inhibit pathogen growth $^{10-12}$, and increase the activity of antimicrobial drugs ${ }^{13}$. Fever potentially benefits infected patients via multiple mechanisms; in vitro and animal studies have shown that elevated temperatures augment immune function, increase production of protective heat shock proteins, directly inhibit microorganism growth, reduce viral replication, and enhance antibiotic effectiveness ${ }^{3,14}$. More rapid recoveries are observed from chickenpox ${ }^{15}$, malaria ${ }^{16}$, and rhinovirus ${ }^{17}$ infections with avoidance of antipyretic medication, and many innate and adaptive immunological processes are accelerated by fever ${ }^{18-20}$. Purposefully inducing hyperthermia has been shown to have positive impacts on the immune system ${ }^{21-27}$. In fact, an approach known as "pyrotherapy" was once widespread, with the originator of the idea, Prof. Wagner-Jauregg, receiving the Nobel Prize in Medicine or Physiology in 192728,29. Recently, a pilot study of external warming of septic patients has been completed ${ }^{30}$.

A core heat trasnfer device (ensoETM, Attune Medical, Chicago, IL) has been commercially available for several years and is used for a range of temperature management purposes, including postcardiac arrest therapeutic hypothermia ${ }^{31-34}$, warming of burn patients ${ }^{35}$, warming general surgical patients ${ }^{36}$, cooling traumatic brain injury ${ }^{37}$, cooling heat stroke ${ }^{38}$, and the treatment of central fever ${ }^{39,40}$. The device is a multichambered silicone tube placed in the esophagus and connected to a heat exchanger to provide heat transfer to or from a patient ${ }^{41}$.

Because of the apparent heightened sensitivity of $2019-\mathrm{nCoV}$ to temperature, in particular to the potential for viral entry to be inhibited by elevations in temperature, elevations in lung temperature, particularly in afebrile patients typically seen late in the disease course, may decrease viral replication and activity sufficiently to affect an improvement in clinical outcome. This approach also avoids the potential for inducing arrhythmias commonly seen with some pharmaceutical treatments being used for COVID-19, such as chloroquine, hydroxychloroquine, azithromycin, and others ${ }^{42,43}$. This work sought to investigate this approach by developing a mathematical model of core warming to determine the temperature distribution throughout lung tissue at typical physiologic conditions.

\section{METHODS}

\section{Mathematical modeling of core warming}

The software Comsol Multiphysics was used to model and simulate heat transfer in the body from an intraesophageal warming device, taking into account the airflow from patient ventilation. The simulation was focused on heat transfer and warming of the lungs and performed on a simplified geometry of an adult human body and airway from the 
pharynx to the lungs. This symmetry was utilized to reduce the computational cost, so only half of the body was simulated, as shown in Fig. 1.

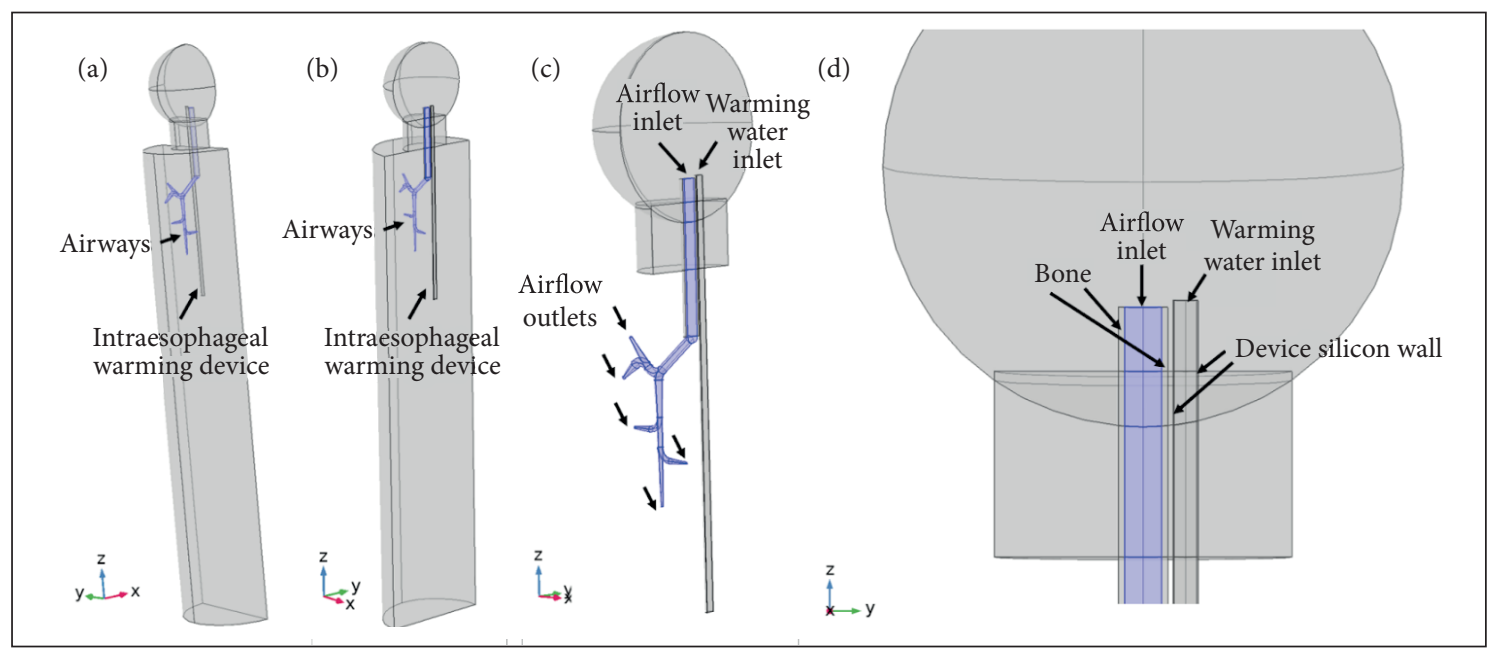

Figure 1. Computational domain. (a) General side view 1, (b) general side view 2, (c) close-up of the airways and intraesophageal warming device, (d) close-up showing details of the relevant domains.

The bioheat transfer interface of Comsol was used for the modeling and simulation of heat transfer, considering the heat generated by the blood perfusion, and known tissue thermal properties ${ }^{44}$. The bioheat transfer governing equations are given by Eq. 1 , where $\mathrm{T}$ is the temperature and is the dependent variable, $\rho$ is the density, $\mathrm{C}_{\mathrm{p}}$ the heat capacity, $\mathrm{k}$ the thermal conductivity, $u$ the velocity field (which is obtained from the fluid flow in the airways) and $\mathrm{Q}_{\text {tio }}$ is the heat generation term with "b" being a subscript corresponding to blood. As the intraesophageal device temperature is higher than the blood temperature in this simulation $\left(\mathrm{Tb}=37^{\circ} \mathrm{C}\right)$, this term has a negative sign, making it a heat consuming term.

$$
\underbrace{\rho C_{p} \frac{\partial T}{\partial t}}_{\text {Transient }}+\underbrace{\rho C_{p} \boldsymbol{u} \cdot \boldsymbol{\nabla T}}_{\text {Convection }}+\underbrace{\boldsymbol{\nabla} \cdot(-k \nabla \mathrm{T})}_{\begin{array}{c}
\text { Diffusion or } \\
\text { Conduction }
\end{array}}=\underbrace{Q_{b i o}=\rho_{b} C_{p, b} \omega_{b}\left(T_{b}-T\right)}_{\text {Blood Perfusion Heat Generation }}
$$

The temperature boundary condition at the warming device inlet was set to $42^{\circ} \mathrm{C}$, the maximum operating temperature of the device. The surrounding air at $20^{\circ} \mathrm{C}$ (emulating a hospital environment) was not considered in the model, but replaced with a convection boundary condition at the skin boundaries.

The airflow was modeled using the turbulent flow, $\mathrm{k}-\varepsilon$ interface considering a stationary study with the RMS value of $0.5 \mathrm{~m} / \mathrm{s}$ of a presumed sinusoidal behavior of the airflow velocity at the inlet of the trachea at the throat level (Fig. 2).

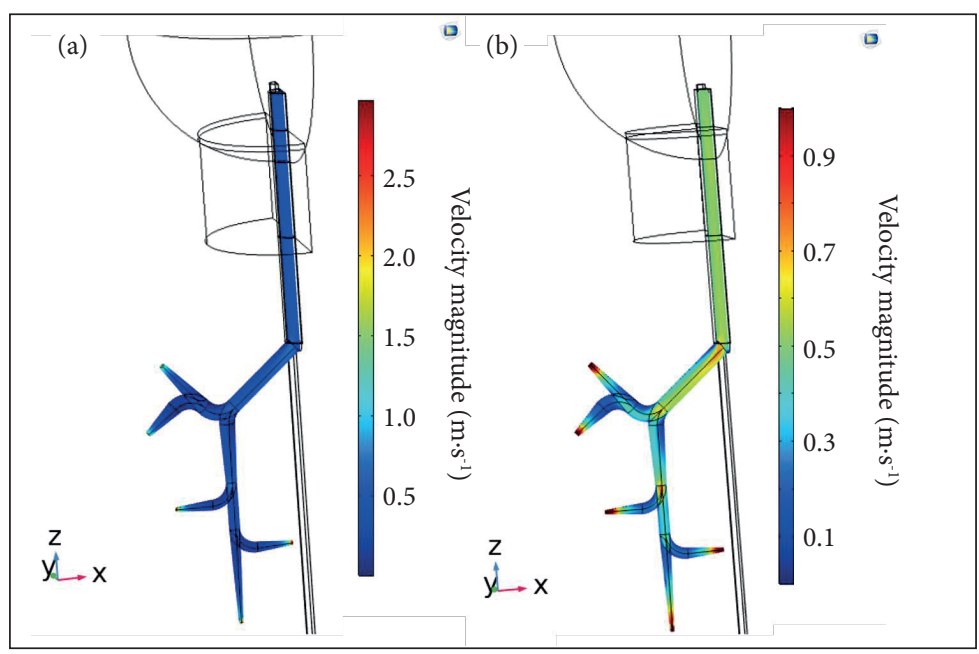

Figure 2. Airflow velocity profile in an xz plane at the center of the airways. (a) Original range and (b) modified range for better visualization. 
The boundary condition in the airflow outlets was set to pressure of $-1 \mathrm{mmHg}$. The warming water flow was directly defined to be $120 \mathrm{~L} / \mathrm{h}$ in the negative $\mathrm{z}$-axis direction, which corresponds to the actual flow rate in the clinical use of the device.

\section{RESULTS}

Simulations were run considering a range of values for the blood perfusion rate, which is a parameter expected to have high influence in the heat consumption term in Eq. 1, since the heat capacity and density remains almost constant. The values considered for the blood perfusion rate were $1 \mathrm{e}-3[1 / \mathrm{s}]$ to $6 \mathrm{e}-3[1 / \mathrm{s}]$ with a step of $1 \mathrm{e}-3[1 / \mathrm{s}]$.

The simulation results show a temperature distribution which agrees with the expected clinical experience, with the skin surface at a lower temperature than the rest of the body due to convective cooling in a typical hospital environment; however, most of the torso is at $37{ }^{\circ} \mathrm{C}$ in the healthy-condition body temperature. The highest temperature in this case is the device warming water temperature, and that heat diffuses by conduction to the nearby tissues, including the air flowing in the airways. With the effective (RMS) value considered for the airflow, warmed air moves through the lungs, and the intraesophageal warming device leads to an increment in the core temperature, as well as in the bronchi from the trachea to the lungs.

The airflow velocity profile is as expected, being around $0.5 \mathrm{~m} / \mathrm{s}$ in the trachea and getting higher as the diameter of the airway decreases (Fig. 2). From Fig. 3, it is evident that the blood perfusion rate affects the temperature distribution, with the heat transfer from the warming device increasing, and the skin temperature decreasing, with a reduced blood perfusion rate. This is seen in Fig. 4, where heat diffuses to the air in the trachea more rapidly, and the temperature has higher values,

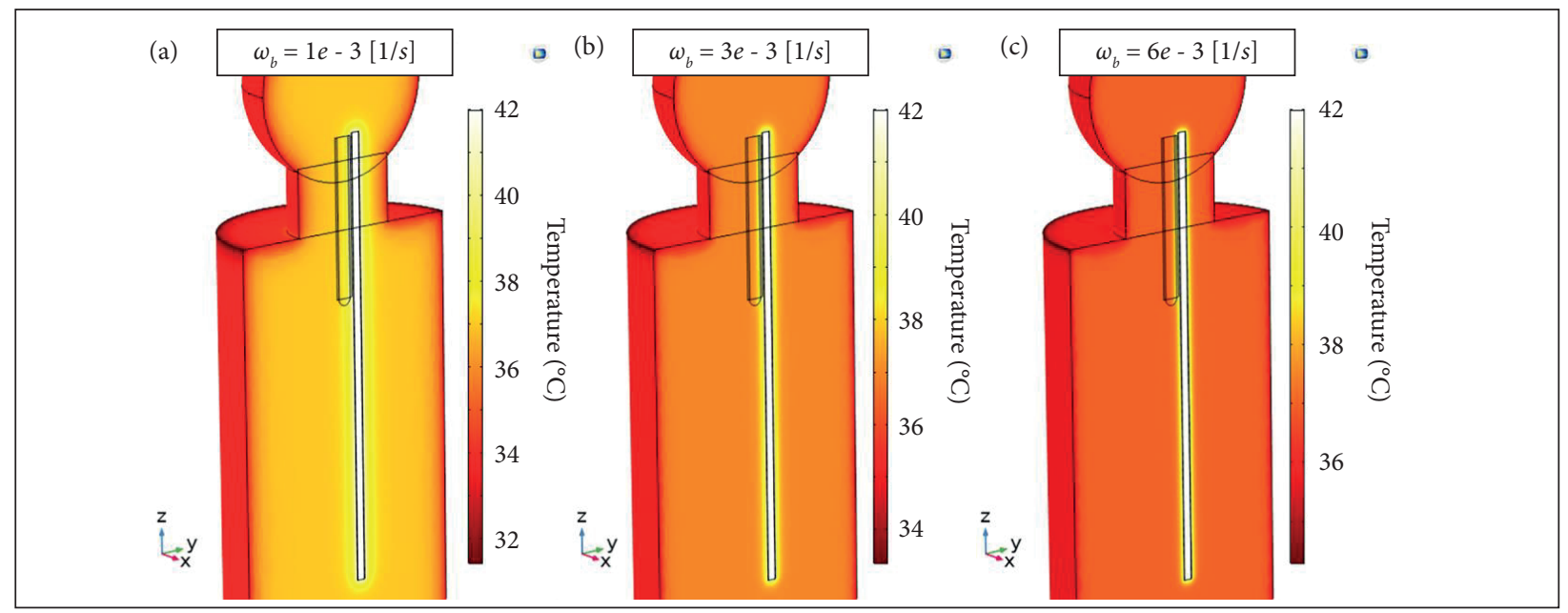

Figure 3. Surface plot of the temperature profile for different blood perfusion rates: (a) 1e-3[1/s], (b) 3e-3[1/s] and (c) 6e-3[1/s]

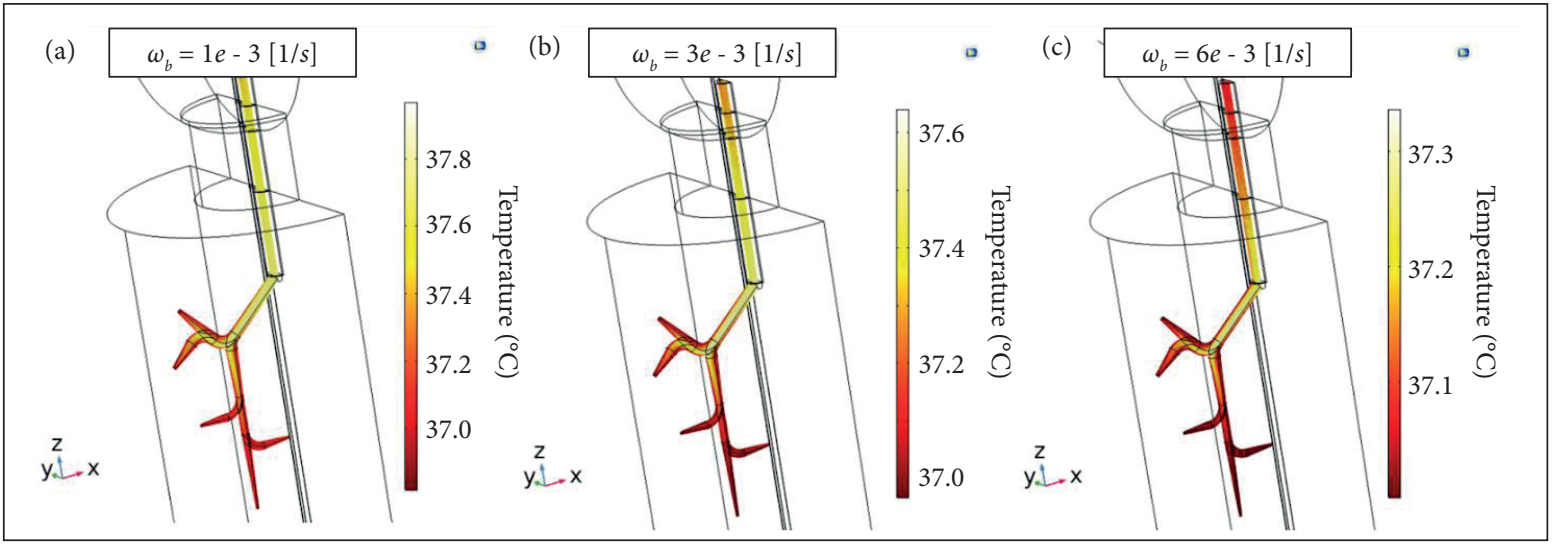

Figure 4. Temperature profile in an xz plane at the center of the airways at different blood perfusion rates: (a) $1 \mathrm{e}-3[1 / \mathrm{s}]$, (b) $3 e-3[1 / \mathrm{s}]$ and (c) $6 \mathrm{e}-3[1 / \mathrm{s}]$. 
at lower blood perfusion rates. The relationship between both the maximum and average temperatures with respect to the blood perfusion rate is exponential in the airways (Fig. 5) as well as in the lungs (Fig. 6). These results are expected given that the blood perfusion heat generation term is a heat consumption term in the warming case considered (Eq. 1).

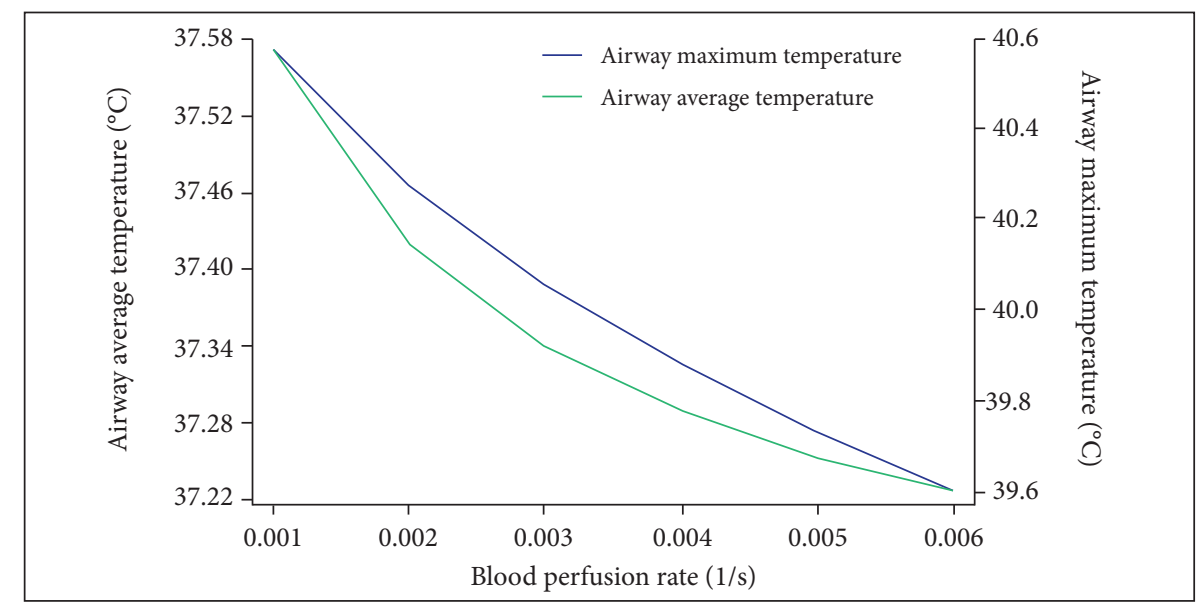

Figure 5. Airway average and maximum temperature as a function of blood perfusion rate.

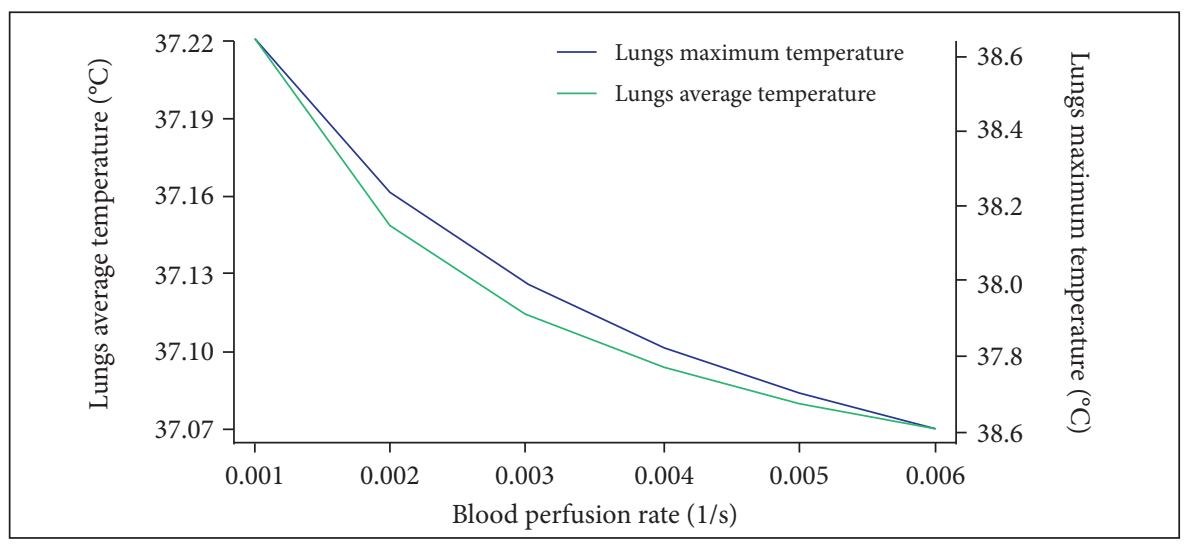

Figure 6. Lungs average and maximum temperature as a function of blood perfusion rate.

\section{DISCUSSION}

At the expected ranges of perfusion in the patient requiring critical-care, this work shows that the temperature of lung tissue, including vasculature and airways, can be elevated to a range that may be sufficient to offer therapeutic benefit. Because currently used pharmaceutical treatments for COVID-19 carry a concerning risk for serious arrhythmias ${ }^{42,43}$, a nonpharmaceutical approach to treatment may be particularly appealing. Multiple randomized control trials evaluating the impact of antipyretic therapy on outcomes in critically ill patients suggest either no benefit, or harm, from treatment ${ }^{45-51}$. Early in acute respiratory distress syndrome (ARDS), fever is associated with improved survival rates; for every $1{ }^{\circ} \mathrm{C}$ increase in baseline temperature, the odds of death decrease by $15 \%$ (odds ratio, $0.85 ; 95 \% \mathrm{CI}, 0.73-0.98, \mathrm{p}=0.03)^{52}$.

A retrospective cohort study of 1,264 patients requiring mechanical ventilation initiated found that high fever $\left(\geq 39.5^{\circ} \mathrm{C}\right)$ was associated with increased risk for mortality in mechanically ventilated patients; however, in patients with sepsis, moderate fever $\left(38.3-39.4^{\circ} \mathrm{C}\right)$ was protective, and antipyretic medication was not associated with changes in outcome ${ }^{53}$. An open, parallel-group pilot randomized clinical trial (the FEVER pilot trial) enrolled 87 pediatric intensive care unit patients who were randomly assigned to permissive (antipyretic interventions only at $\geq 39.5^{\circ} \mathrm{C}$ ) or restrictive groups (antipyretic interventions 
at $\geq 37.5^{\circ} \mathrm{C}$ ) whilst on respiratory support, and found that length of stay, duration of organ support and mortality were similar between groups, and no prespecified serious adverse events occurred ${ }^{18}$. The UK National Institute for Health and Care Excellence (NICE) now recommend not using antipyretic agents "with the sole aim of reducing body temperature in children with fever."18,54.

Coronavirus disease 2019 (COVID-19) and its causative virus (SARS-CoV-2) were first identified in December 2019, with mortality initially estimated at $5.7 \% \%^{55}$. The surface glycoprotein of an earlier SARS coronavirus (SARS-CoV), SARS-S, consists of two components: $\mathrm{S} 1$, which contains the receptor binding domain (RBD); and $\mathrm{S} 2$, which contains the fusion peptide. Permissive host alveolar epithelial cells are initially bound to the SARS virus at the glycosaminoglycan heparan sulfate. Heparan sulfate expression increases viral density, facilitating the SARS-S predilection for the cell surface receptor angiotensin converting enzyme 2 (ACE2) ${ }^{56,57}$. Following these binding steps, SARS CoV undergoes endocytosis into low $\mathrm{pH}$ endosomes, where viral RNA replication initiates. ACE2 is a membrane associated enzyme expressed in human endothelial cells identified in 2000, found in heart, kidneys, testis, and the lungs ${ }^{58,59}$.

Most isolates of human rhinovirus, the common cold virus, replicate more robustly at the cool temperatures found in the nasal cavity $\left(33-35^{\circ} \mathrm{C}\right)$ than at core body (lung) temperature $\left(37^{\circ} \mathrm{C}\right)^{60}$. Rhinovirus replicates preferentially at cooler nasal cavity temperature due, in part, to a less efficient antiviral defense response of infected cells at cool temperature, raising the possibility that inhaling cool air might diminish resistance to respiratory virus infections by lowering the temperature of potential host cells lining the nasal cavity ${ }^{60}$.

Influenza B virus viral hemagglutinin exhibits higher expression at $33^{\circ} \mathrm{C}$ (a temperature required for membrane fusion), indicating pronounced adaptation to the mildly acidic $\mathrm{pH}$ and cooler temperature of human upper airways ${ }^{61}$. Specifically, protein expression of influenza $\mathrm{B}$ virus viral hemagglutinin proved to be temperature dependent, with expression highest at $33{ }^{\circ} \mathrm{C}$ and gradually decreasing at higher temperatures ${ }^{61}$. More recently, simulations of the receptor binding domain (RBD) of 2019-nCoV found that it is more flexible than SARS CoV, especially near the binding site, suggesting that the RBD will have a higher entropy penalty upon binding angiotensin-converting enzyme II (ACE2) compared to the RBD of SARS-CoV ${ }^{62}$. Consequently, 2019-nCoV may be more temperature-sensitive in terms of human infection than SARS-CoV ${ }^{62}$.

A study investigating the distribution of SARS-CoV-2 in different tissues of 205 patients with laboratory confirmed COVID-19 disease found that while lower respiratory tract samples were more likely to be positive, nasal swabs had the lowest mean RT PCR cycle threshold value of 24.3 (or $1.4 \times 10^{6}$ copies $/ \mathrm{mL}$ ), indicating higher viral loads than all other specimen types including sputum, pharyngeal swabs and bronchoalveolar lavage fluid, which all had a cycle threshold of over $30\left(<2.6 \times 10^{4} \mathrm{copies} / \mathrm{mL}\right)^{63}$. Higher viral loads were also detected in the nose than in the throat in 17 symptomatic patients in Wuhan ${ }^{64}$. In a study of the stability of SARS $\mathrm{CoV}$ virus at different temperatures and relative humidity on smooth surfaces, virus viability was rapidly $\operatorname{lost}(>3 \log 10)$ at higher temperatures and higher relative humidity (e.g., $38^{\circ} \mathrm{C}$, and relative humidity of $\left.>95 \%\right)^{65}$.

In summary, core warming appears to be feasible, and existing knowledge of immune system function and viral physiology suggests this may approach be of clinical benefit. A proposed protocol has recently been posted ${ }^{66}$.

\section{CONCLUSION}

The provision of core warming via technology commonly utilized in the intensive care unit, emergency department, and operating room can increase regional temperature of lung tissue and airway passages. The characteristics of many viruses, and in particular, the temperature sensitivities of SARS-CoV-2, combined with increasing evidence of potential benefits of elevated body temperature in treating infectious conditions suggests that core warming may offer a novel treatment option while avoiding the arrhythmogenic complications of many currently used pharmaceutical treatments.

\section{CONFLICT OF INTEREST}

Erik Kulstad and Konstantin Kostov declare equity interest in Attune Medical; Marcela Mercado-Montoya performs consulting for, and Shailee Shah has served as an intern for, and now serves as Operations and Quality Engineer for Attune Medical. 


\section{REFERENCES}

1. Mohr NM, Doerschug KC. Point: should antipyretic therapy be given routinely to febrile patients in septic shock? Yes. Chest. 2013;144(4):1096-8. https://doi.org/10.1378/chest.13-0916

2. Ray JJ, Schulman Cl. Fever: suppress or let it ride? J Thorac Dis. 2015;7(12):E633-6. https://doi.org/10.3978/j.issn.20721439.2015.12.28

3. Drewry AM, Hotchkiss RS. Counterpoint: should antipyretic therapy be given routinely to febrile patients in septic shock? No. Chest. 2013;144(4):1098-101. https://doi.org/10.1378/chest.13-0918

4. O'Grady NP, Barie PS, Bartlett JG, Bleck T, Carroll K, Kalil AC, et al. Guidelines for evaluation of new fever in critically ill adult patients: 2008 update from the American College of Critical Care Medicine and the Infectious Diseases Society of America. Crit Care Med. 2008;36(4):1330-49. https://doi.org/10.1097/CCM.0b013e318169eda9

5. Schortgen F, Clabault K, Katsahian S, Devaquet J, Mercat A, Deye N, et al. Fever control using external cooling in septic shock a randomized controlled trial. Am J Respir Crit Care Med. 2012;185(10):1088-95. https://doi.org/10.1164/rccm.201110$18200 C$

6. Saxena M, Young P, Pilcher D, Bailey M, Harrison D, Bellomo R, et al. Early temperature and mortality in critically ill patients with acute neurological diseases: trauma and stroke differ from infection. Intensive Care Med. 2015;41(5):823-32. https:// doi.org/10.1007/s00134-015-3676-6

7. Young PJ, Saxena M, Beasley R, Bellomo R, Bailey M, Pilcher D, et al. Early peak temperature and mortality in critically ill patients with or without infection. Intensive Care Med. 2012;38(3):437-44. https://doi.org/10.1007/s00134-012-2478-3

8. Berman JD, Neva FA. Effect of temperature on multiplication of Leishmania amastigotes within human monocyte-derived macrophages in vitro. Am J Trop Med Hyg. 1981;30(2):318-21. https://doi.org/10.4269/ajtmh.1981.30.318

9. Mace TA, Zhong L, Kilpatrick C, Zynda E, Lee C-T, Capitano M, et al. Differentiation of CD8+ T cells into effector cells is enhanced by physiological range hyperthermia. J Leukoc Biol. 2011;90(5):951-62. https://doi.org/10.1189/jlb.0511229

10. Chu CM, Tian SF, Ren GF, Zhang YM, Zhang LX, Liu GQ. Occurrence of temperature-sensitive influenza A viruses in nature. J Virol. 1982;41(2):353-9. https://doi.org/10.1128/JVI.41.2.353-359.1982

11. Moench LM. A study of the heat sensitivity of the meningoeoecus in vitro within the range of therapeutic temperatures. J Lab Clin Med. 1937;22:665-76.

12. Small PM, Täuber MG, Hackbarth CJ, Sande MA. Influence of body temperature on bacterial growth rates in experimental pneumococcal meningitis in rabbits. Infect Immun. 1986;52(2):484-7. https://doi.org/10.1128//AI.52.2.484-487.1986

13. Mackowiak PA, Ruderman E, Martin RM, Many WJ, Smith JW, Luby JP. Effects of physiologic variations in temperature on the rate of antibiotic-induced bacterial killing. Am J Clin Pathol. 1981;76(1):57-62. https://doi.org/10.1093/ajcp/76.1.57

14. Launey $Y$, Nesseler N, Mallédant Y, Seguin P. Clinical review: fever in septic ICU patients - friend or foe? Crit Care. 2011;15:222. https://doi.org/10.1186/cc10097

15. Doran TF, Angelis C, Baumgardner RA, Mellits ED. Acetaminophen: More harm than good for chickenpox? J Pediatr. 1989;114(6):1045-8. https://doi.org/10.1016/S0022-3476(89)80461-5

16. Brandts CH, Ndjavé M, Graninger W, Kremsner PG. Effect of paracetamol on parasite clearance time in Plasmodium falciparum malaria. Lancet. 1997;350(9079):704-9. https://doi.org/10.1016/S0140-6736(97)02255-1

17. Stanley ED, Jackson GG, Panusarn C, Rubenis M, Dirda V. Increased virus shedding with aspirin treatment of rhinovirus infection. JAMA. 1975;231(12):1248-51. https://doi.org/10.1001/jama.1975.03240240018017

18. Peters MJ, Woolfall K, Khan I, Deja E, Mouncey PR, Wulff J, et al. Permissive versus restrictive temperature thresholds in critically ill children with fever and infection: a multicentre randomized clinical pilot trial. Crit Care. 2019;23:69. https://doi. org/10.1186/s13054-019-2354-4

19. Evans SS, Repasky EA, Fisher DT. Fever and the thermal regulation of immunity: the immune system feels the heat. Nat Rev Immunol. 2015;15(6):335-49. https://doi.org/10.1038/nri3843

20. Lee C-T, Zhong L, Mace TA, Repasky EA. Elevation in body temperature to fever range enhances and prolongs subsequent responsiveness of macrophages to endotoxin challenge. PLOS ONE. 2012;7(1):e30077. https://doi.org/10.1371/journal. pone.0030077 
21. Van der Zee J. Heating the patient: a promising approach? Ann Oncol. 2002;13(8):1173-84. https://doi.org/10.1093/annonc/ mdf280

22. Bull JMC. Clinical practice of whole-body hyperthermia: new directions. In: Seegenschmiedt MH, Fessenden P, Vernon CC. (Ed.). Thermoradiotherapy and thermochemotherapy: clinical applications. Berlin: Springer; 1996. https://doi. org/10.1007/978-3-642-60938-1_18

23. Westermann AM, Grosen EA, Katschinski DM, Jäger D, Rietbroek R, Schink JC, et al. A pilot study of whole body hyperthermia and carboplatin in platinum-resistant ovarian cancer. Eur J Cancer. 2001;37(9):1111-7. https://doi.org/10.1016/S09598049(01)00074-0

24. Robins HI, Dennis WH, Neville AJ, Shecterle LM, Martin PA, Grossman J, et al. A nontoxic system for 41.8 degrees c wholebody hyperthermia: results of a Phase I study using a radiant heat device. Cancer Res. 1985;45(8):3937-44.

25. Shi H, Cao T, Connolly JE, Monnet L, Bennett L, Chapel S, et al. Hyperthermia enhances CTL cross-priming. J Immunol Res. 2006;176(4):2134-41. https://doi.org/10.4049/jimmunol.176.4.2134

26. Basu S, Srivastava PK. Fever like temperature induces maturation of dendritic cells through induction of hsp90. Int Immunol. 2003;15(9):1053-61. https://doi.org/10.1093/intimm/dxg104

27. Tsan M-F, Gao B. Heat shock proteins and immune system. J Leukoc Biol. 2009;85(6):905-10. https://doi.org/10.1189/ jlb.0109005

28. Raju TNK. Hot brains: manipulating body heat to save the brain. Pediatrics. 2006;117(2):e320-1. https://doi.org/10.1542/ peds.2005-1934

29. Epstein NN. Artificial Fever as a Therapeutic Procedure. Cal West Med. 1936;44(5):357-8.

30. Washington University School of Medicine. Pilot Randomized Trial of External Warming in Critically III Adult Septic Patients [Internet]. Saint Louis: ClinicalTrials.gov. 2020. [cited 27 May 2020]. Available at: https://clinicaltrials.gov/ct2/show/ NCT02706275

31. Goury A, Poirson F, Chaput U, Voicu S, Garçon P, Beeken T, et al. Targeted temperature management using the "Esophageal Cooling Device" after cardiac arrest (the COOL study): A feasibility and safety study. Resuscitation. 2017;121:54-61. https:// doi.org/10.1016/j.resuscitation.2017.09.021

32. Hegazy AF, Lapierre DM, Butler R, Martin J, Althenayan E. The esophageal cooling device: A new temperature control tool in the intensivist's arsenal. Heart Lung. 2017;46(3):143-8. https://doi.org/10.1016/j.hrtlng.2017.03.001

33. Markota A, Fluher J, Kit B, Balažič P, Sinkovič A. The introduction of an esophageal heat transfer device into a therapeutic hypothermia protocol: a prospective evaluation. Am J Emerg Med. 2016;34(4):741-5. https://doi.org/10.1016/j. ajem.2016.01.028

34. Khan I, Haymore J, Barnaba B, Armahizer M, Melinosky C, Bautista MA, et al. Esophageal cooling device versus other temperature modulation devices for therapeutic normothermia in subarachnoid and intracranial hemorrhage. Ther Hypothermia Temp Manag. 2018;8(1):53-8. https://doi.org/10.1089/ther.2017.0033

35. Williams D, Leslie G, Kyriazis D, O'Donovan B, Bowes J, Dingley J. Use of an esophageal heat exchanger to maintain core temperature during burn excisions and to attenuate pyrexia on the burns intensive care unit. Case Rep Anesthesiol. 2016;2016:7306341. https://doi.org/10.1155/2016/7306341

36. Kalasbail P, Makarova N, Garrett F, Sessler DI. Heating and cooling rates with an esophageal heat exchange system. Anesth Analg. 2018;126(4):1190-5. https://doi.org/10.1213/ANE.0000000000002691

37. Bhatti F, Naiman M, Tsarev A, Kulstad E. Esophageal temperature management in patients suffering from traumatic brain injury. Ther Hypothermia Temp Manag. 2019;9(4):238-42. https://doi.org/10.1089/ther.2018.0034

38. Martin KR, Naiman M, Espinoza M. Using esophageal temperature management to treat severe heat stroke: a case report. J Neurosci Nurs. 2020;52(1):9-3. https://doi.org/10.1097/JNN.0000000000000488

39. Hegazy AF, Lapierre DM, Butler R, Althenayan E. Temperature control in critically ill patients with a novel esophageal cooling device: a case series. BMC Anesthesiology. 2015;15:152. https://doi.org/10.1186/s12871-015-0133-6

40. Markota A, Košir AS, Balažič P, Živko I, Sinkovič A. A novel esophageal heat transfer device for temperature management in an adult patient with severe meningitis. Int J Emerg Med. 2017;52(1):e27-8. https://doi.org/10.1016/j.jemermed.2016.07.086 
41. ensoETM. Placing ensoETM [video online]. Illinois: Vimeo. 2018. Video: 50 sec. [cited 27 May 2020]. Available at: https:// vimeo.com/306506411

42. Roden DM, Harrington RA, Poppas A, Russo AM. Considerations for drug interactions on QTC in exploratory COVID-19 (coronavirus disease 2019) treatment. Heart Rhythm. Forthcoming 2020. https://doi.org/10.1161/ CIRCULATIONAHA.120.047521

43. Sapp JL, Alqarawi W, Maclntyre CJ, Tadros R, Steinberg C, Roberts JD, et al. Guidance on minimizing risk of drug-induced ventricular arrhythmia during treatment of covid-19: a statement from the Canadian Heart Rhythm Society. Can J Cardiol. Forthcoming 2020. https://doi.org/10.1016/j.cjca.2020.04.003

44. Hasgall PA, Di Gennaro F, Baumgartner C, Neufeld E, Lloyd B, Gosselin MC, et al. IT'IS Database for thermal and electromagnetic parameters of biological tissues [Internet]. Version 4.0. Tissue Properties. 2018. [cited 27 May 2020]. Available at: itis.swiss/ database

45. Schulman Cl, Namias N, Doherty J, Manning RJ, Li P, Elhaddad A, et al. The effect of antipyretic therapy upon outcomes in critically ill patients: a randomized, prospective study. Surg Infect. 2005;6(4):369-75. https://doi.org/10.1089/sur.2005.6.369

46. Gozzoli V, Schöttker P, Suter PM, Ricou B. Is it worth treating fever in intensive care unit patients? Preliminary results from a randomized trial of the effect of external cooling. Arch Intern Med. 2001;161(1):121-3. https://doi.org/10.1001/ archinte.161.1.121

47. Young P, Saxena M, Bellomo R, Freebairn R, Hammond N, van Haren F, et al. Acetaminophen for fever in critically ill patients with suspected infection. N Engl J Med. 2015;373(23):2215-24. https://doi.org/10.1056/NEJMoa1508375

48. Zhang Z. Antipyretic therapy in critically ill patients with established sepsis: A Trial Sequential Analysis. PLoS ONE. 2015;10(2):e0117279. https://doi.org/10.1371/journal.pone.0117279

49. Dallimore J, Ebmeier S, Thayabaran D, Bellomo R, Bernard G, Schortgen F, et al. Effect of active temperature management on mortality in intensive care unit patients. Crit Care Resusc. 2018;20(2):150-63.

50. Drewry AM, Ablordeppey EA, Murray ET, Stoll CRT, Izadi SR, Dalton CM, et al. Antipyretic therapy in critically ill septic patients: a systematic review and meta-analysis. Crit Care Med. 2017;45(5):806-13. https://doi.org/10.1097/CCM.0000000000002285

51. Niven DJ, Stelfox HT, Laupland KB. Antipyretic therapy in febrile critically ill adults: A systematic review and meta-analysis. J Crit Care. 2013;28(3):303-10. https://doi.org/10.1016/j.jcrc.2012.09.009

52. Schell-Chaple HM, Puntillo KA, Matthay MA, Liu KD, the National Heart, Lung, and Blood Institute Acute Respiratory Distress Syndrome Network. Body temperature and mortality in patients with acute respiratory distress syndrome. Am J Crit Care. 2015;24(1):15-23. https://doi.org/10.4037/ajcc2015320

53. Evans EM, Doctor RJ, Gage BF, Hotchkiss RS Fuller BM, Drewry AM. The association of fever and antipyretic medication with outcomes in mechanically ventilated patients: a cohort study. Shock. 2019;52(2):152-9. https://doi.org/10.1097/ SHK.0000000000001368

54. Davis T. NICE guideline: feverish illness in children-assessment and initial management in children younger than 5 years. Arch Dis Child Educ Pract Ed. 2013;98(6):232-5. https://doi.org/10.1136/archdischild-2013-304792

55. Baud D, Qi X, Nielsen-Saines K, Musso D, Pomar L, Favre G. Real estimates of mortality following COVID-19 infection. Lancet Infect Dis. Published online March 12, 2020. https://doi.org/10.1016/S1473-3099(20)30195-X

56. Adedeji AO, Severson W, Jonsson C, Singh K, Weiss SR, Sarafianos SG. Novel inhibitors of severe acute respiratory syndrome coronavirus entry that act by three distinct mechanisms. J Virol. 2013;87(14):8017-28. https://doi.org/10.1128/JVI.00998-13

57. Aquino RS, Park PW. Glycosaminoglycans and infection. Front Biosci. 2016;21:1260-77. https://doi.org/10.2741/4455

58. Donoghue M, Hsieh F, Baronas E, Godbout K, Gosselin M, Stagliano N, et al. A novel angiotensin-converting enzyme-related carboxypeptidase (ACE2) converts angiotensin i to angiotensin 1-9. Circ Res. 2000;87(5):e1-9. https://doi.org/10.1161/01. RES.87.5.e1

59. Li W, Moore MJ, Vasilieva N, Sui J, Wong SK, Berne MA, et al. Angiotensin-converting enzyme 2 is a functional receptor for the SARS coronavirus. Nature. 2003;426(6965):450-4. https://doi.org/10.1038/nature02145

60. Foxman EF, Storer JA, Fitzgerald ME, Wasik BR, Hou L, Zhao H, et al. Temperature-dependent innate defense against the common cold virus limits viral replication at warm temperature in mouse airway cells. Proc Natl Acad Sci. 2015;112(3):82732. https://doi.org/10.1073/pnas.1411030112 
61. Laporte M, Stevaert A, Raeymaekers V, Boogaerts T, Nehlmeier I, Chiu W, et al. Hemagglutinin cleavability, acid stability, and temperature dependence optimize Influenza B virus for replication in human airways. J Virol. 2019;94(1):e01430-19. https:// doi.org/10.1128/JVI.01430-19

62. He J, Tao H, Yan Y, Huang S-Y, Xiao Y. Molecular mechanism of evolution and human infection with SARS-CoV-2. Viruses. 2020;12(4):428. https://doi.org/10.3390/v12040428

63. Wang W, Xu Y, Gao R, Lu R, Han K, Wu G, et al. Detection of SARS-CoV-2 in different types of clinical specimens. JAMA. 2020;323(18):1843-44. https://doi.org/10.1001/jama.2020.3786

64. Zou L, Ruan F, Huang M, Liang L, Huang H, Hong Z, et al. SARS-CoV-2 Viral load in upper respiratory specimens of infected patients. N Engl J Med. 2020;382(12):1177-9. https://doi.org/10.1056/NEJMc2001737

65. Chan KH, Peiris JSM, Lam SY, Poon LLM, Yuen KY, Seto WH. The effects of temperature and relative humidity on the viability of the SARS coronavirus. Adv Virol. 2011;2011:734690. https://doi.org/10.1155/2011/734690

66. Bonfanti N, Gundert E, Goff K, Drewry A, Bedimo R, Kulstad E. Core warming of coronavirus disease 2019 (COVID-19) patients undergoing mechanical ventilation: protocol for a randomized controlled pilot study. medRxiv. Forthcoming 2020. https://doi.org/10.1101/2020.04.03.20052001 